\title{
DANGEROUS TALES: DOMINANT NARRATIVES ON THE CONGO AND THEIR UNINTENDED CONSEQUENCES
}

\author{
SÉVERINE AUTESSERRE*
}

\begin{abstract}
Explanations for the persistence of violence in the eastern part of the Democratic Republic of Congo blame the incendiary actions of domestic and regional leaders, as well as the inefficacy of international peacebuilding efforts. Based on several years of ethnographic research, this article adds another piece to the puzzle, emphasizing the perverse consequences of well-meaning international efforts. I argue that three narratives dominate the public discourse on Congo and eclipse the numerous alternative framings of the situation. These narratives focus on a primary cause of violence, illegal exploitation of mineral resources; a main consequence, sexual abuse of women and girls; and a central solution, extending state authority. I elucidate why simple narratives are necessary for policy makers, journalists, advocacy groups, and practitioners on the ground, especially those involved in the Congo. I then consider each narrative in turn and explain how they achieved prominence: they provided straightforward explanations for the violence, suggested feasible solutions to it, and resonated with foreign audiences. I demonstrate that the focus on these narratives and on the solutions they recommended has led to results that clash with their intended purposes, notably an increase in human rights violations.
\end{abstract}

LIFE CONDITIONS IN THE EASTERN PART of the Democratic Republic of Congo have deteriorated significantly since the end of the transition to peace and democracy in late 2006. Each year, the people of the eastern

\footnotetext{
*Séverine Autesserre (sa435@columbia.edu) is Assistant Professor of Political Science at Barnard College, Columbia University. My deepest thanks go to my interviewees, to all the people who have gone out of their way to facilitate my fieldwork, and to the many colleagues with whom I have brainstormed on the topics of this article. Research for this project was funded by the United States Institute of Peace, the Harry Frank Guggenheim Foundation, as well as Barnard College and the Earth Institute at Columbia University. Anneke DunbarGronke and Brian Abelson provided excellent research and editing assistance. I thank Maria Eriksson Baaz, René Lemarchand, Sarah Lischer, Philippe Rosen, the editors and anonymous reviewers of African Affairs, and the participants in the various events during which I presented my research, for very helpful comments on drafts of this article. The views I expressed do not necessarily reflect the views of my donors or colleagues, and any errors in the text are mine alone.
} 
provinces feel less secure than the year before. ${ }^{1}$ There were more people internally displaced in 2010 than at the end of $2006 .^{2}$ Armed groups, including the Congolese army, relentlessly commit horrific violations of human rights. The Congo has dropped twenty places (from 167 to 187) in the Index of Human Development, officially becoming the least developed country on earth. ${ }^{3}$ Overall, current conditions for the populations of the eastern Congo remain among the worst in Africa.

There are many reasons for the deterioration of the situation, notably incendiary actions by domestic and regional leaders, grassroots antagonisms over land and power, and the persistence of corruption at all levels of the political and economic system. A number of recent studies have convincingly analysed these internal dynamics, as well as those at the level of the Great Lakes region, and shown their nefarious effects. ${ }^{4}$ In addition, a few researchers have explored why the international efforts at building peace and democracy have failed. ${ }^{5}$ This article takes the analysis one step further and considers how, despite a number of positive results, the international efforts themselves have contributed to the degradation of the situation.

This article focuses on the negative consequences of external efforts that aim to help the Congo build peace and democracy. These include advocacy campaigns in Europe and North America, as well as humanitarian, development, and peace-building initiatives implemented in the eastern Congo by non-governmental organizations (NGOs), the diplomatic representations of various states, and international organizations such as the United Nations (UN) and the African Union.

There is no doubt that these international efforts have achieved many positive results. Re-establishing peace, albeit a precarious one, over most of the Congolese territory would not have been possible without the

1. See the protection investigations that Oxfam conducted between 2007 and 2010, notably the latest one, 'Les femmes et les enfants d'abord: sur la ligne de front aux Kivus' (Oxfam, Oxford, June 2010).

2. Internal Displacement Monitoring Centre, 'Democratic Republic of Congo - IDP figures by year', <www.internaldisplacement.org/idmc/website/countries.nsf/\%28http Envelopes\%29/96849E3579EE3240C12577FC0044524A?OpenDocument\#15.3.1> (23 June 2011).

3. UN Development Programme, 'Human Development Index' (reports, UNDP, New York, 2006 and 2011).

4. Séverine Autesserre, The Trouble with the Congo: Local violence and the failure of international peacebuilding (Cambridge University Press, New York, NY, 2010); René Lemarchand, The Dynamics of Violence in Central Africa (University of Pennsylvania Press, Philadelphia, PA, 2008); Filip Reyntjens, The Great African War: Congo and regional geopolitics, 1996-2006 (Cambridge University Press, New York, NY, 2009); Thomas Turner, The Congo Wars: Conflict, myth and reality (Palgrave Macmillan, New York, NY, 2007); and Koen Vlassenroot and Timothy Raeymaekers, Conflict and Social Transformation in Eastern DR Congo (Academia Press Scientific Publishers, Ghent, 2004).

5. See notably Autesserre, The Trouble with the Congo, and Théodore Trefon, Congo Masquerade: The political culture of aid inefficiency and reform failure (Zed Books, London, 2011). 
presence of the UN peacekeeping mission and the work of African and Western diplomats. Likewise, it is mostly thanks to these interveners that the Congo managed to organize its first democratic elections in 2006. As of the time of this writing, the UN mission remains the only military force capable of protecting the population from the exactions of the Congolese army and various other armed groups. Humanitarian agencies are the only ones able to respond to epidemics and, in the eastern provinces, to provide access to drinkable water and basic health care. However, aside from these encouraging aspects, the interventions have also produced a series of detrimental outcomes.

In the past five years, three narratives have dominated the discourse on the Congo and oriented the intervention strategies. These narratives focus on a primary cause of violence, the illegal exploitation of natural resources; a main consequence, sexual abuse against women and girls; and a central solution, reconstructing state authority. ${ }^{6}$ There is no doubt that the illegal exploitation of Congolese mineral resources is a significant cause of conflict, that sexual violence is a terrible and widespread form of abuse, and that reconstructing state authority is an essential measure. However, we can wonder how the illegal exploitation of resources came to be seen as the main cause of violence, sexual abuse as the worst consequence, and the extension of state authority as the primary solution to the conflict, to the exclusion of other causes, consequences, and solutions.

This article considers three central questions: Why use simple narratives? Why these three in particular, and not any of the numerous alternative framings of the situation? What are the effects of the exclusive focus on this specific cause, consequence, and solution? While my answers to the first two questions demonstrate that interveners had good reasons for adopting dominant, simple narratives, and for focusing on three of them, my answer to the third question demonstrates that this adoption had some positive results, but was damaging overall.

The use of these three narratives has enabled advocates to put the Congo on the agenda of some of the most powerful states and organizations, and thus prompted action to end what remains a 'forgotten conflict'. ${ }^{7}$ However, I argue that the well-meaning international efforts have also had unintended ramifications that have prevented the intervention from achieving its stated goals, and that have even, at times, contributed

6. The advocacy documents produced by Enough <www.enoughproject.org > and Friends of the Congo <www.friendsofthecongo.org> provide a perfect illustration of this focus. For a claim similar to mine regarding the first two narratives, see the recurrent debates in the blogs Texas in Africa (by Laura Seay, texasinafrica.blogspot.com) and Congo Siasa (by Jason Stearns, www.congosiasa.blogspot.com).

7. On the categorization of the Congo as a forgotten conflict, see Médecins Sans Frontières' yearly list of the 'Top Ten Most Underreported Humanitarian Stories' <www. doctorswithoutborders.org/news/issue.cfm?id=2403\&ref=tag-index > (21 November 2011). 
to the deterioration of the situation in the eastern Congo. The international actors' concentration on trafficking of mineral resources as a source of violence has led them to overlook the myriad other causes, such as land conflict, poverty, corruption, local political and social antagonisms, and hostile relationships between state officials, including security forces, and the general population. Interveners have singled out for support one category of victims, sexually injured women and girls, at the expense of others, notably those tortured in a non-sexual manner, child soldiers, and the families of those killed. The dominant narratives have oriented international programmes on the ground toward three main goals - regulating trade of minerals, providing care to victims of sexual violence, and helping the state extend its authority - at the expense of all the other necessary measures, such as resolving land conflict, promoting inter-community reconciliation, jump-starting economic development, ensuring that state authorities respect human rights, and fighting corruption. Even worse, because of these exclusive focuses, the international efforts have exacerbated the problems that they aimed to combat: the attempts to control the exploitation of resources have enabled armed groups to strengthen their control over mines; the disproportionate attention to sexual violence has raised the status of sexual abuse to an effective bargaining tool for combatants; and the state reconstruction programmes have boosted the capacity of an authoritarian regime to oppress its population.

To develop this analysis, I first explain why policy makers and practitioners need simple narratives in order to work, and why it is especially important for those involved in the Congo. I then consider each of the three dominant narratives in turn. For each case, I present the narrative, locate its sources, and explain why it has become dominant over competing narratives. I then show how it has oriented international intervention strategies on the ground, acknowledging the positive outcomes and highlighting the main negative consequences.

This article draws on a year of ethnographic research conducted in the eastern Congo from June 2010 to July 2011. During that time, I investigated mainly the situation in North Kivu - the most violent area of the Congo during my fieldwork - but I also gathered data on the other unstable provinces, notably South Kivu, North Katanga, and Oriental Province, as well as in the capital city of Kinshasa. In addition, I completed three short trips to Europe and North America to study the perception of the eastern Congo among interveners based in capitals and headquarters.

Overall, I have gathered data from more than 170 in-depth interviews with international interveners and Congolese stakeholders. I also draw on field observations, analysis of key policy papers, and participant 
observation. The latter research method consisted of patrolling with military peacekeepers, implementing state reconstruction programmes with UN officials, assisting community reconciliation projects with NGOs, participating in dozens of coordination meetings, and training, briefing, and advising NGOs, diplomatic missions, peacekeeping sections, and other agencies. Furthermore, this article builds on ten years of ethnographic research in the Congo that I conducted between 2001 and 2010 for an earlier project, including more than 330 in-depth interviews and a year and a half of fieldwork.

Virtually all of my contacts asked to remain anonymous in view of the personal and professional risks involved in providing information on the topics analysed in this article. For this reason, I fully reference only the data obtained through on-the-record interviews and from public sources. All the information and quotations that I do not fully reference come from confidential interviews and participant observation.

\section{The power of simple narratives}

The study of narratives permeates a number of disciplines, from its dominance in literature to its occasional use by interpretive social scientists. ${ }^{8}$ Simply put, a narrative is a story that people create to make sense of their lives and environments. For the purpose of this article, the most important feature of narratives is that they help shape the way we perceive the social and material worlds, and thus orient how we act upon our environment.

Narratives include a central frame, or a combination of frames. ${ }^{9}$ Frames are essential to the social world since problems are not given, but have to be constructed. Frames shape our views on what counts as a problem (for example, the illegal exploitation of mining resources) and what does not (for instance, land conflicts). Frames also affect which events will be noticed (sexual violence) and which will not (non-sexual torture), as well

8. This paragraph draws on H. Porter Abbott, The Cambridge Introduction to Narrative (Cambridge University Press, Cambridge, 2008); Anna de Fina and Alexandra Georgakopoulou, 'Analysing narratives as practices', Qualitative Research 8, 3 (2008), pp. 379-87; and Molly Patterson and Kristen Renwick Monroe, 'Narrative in political science', Annual Review of Political Science 1 (1998), pp. 315-31.

9. This paragraph draws on Séverine Autesserre, 'Hobbes and the Congo: frames, local violence, and international intervention', International Organization 63, 2 (2009), pp. 24980. It builds mainly on Michael Barnett and Martha Finnemore, Rules for the World: International organizations in global politics (Cornell University Press, Ithaca, NY, 2004); Lynn Eden, Whole World on Fire: Organizations, knowledge, and nuclear weapons devastation (Cornell University Press, Ithaca, NY, 2004); Martha Finnemore, 'Norms, culture, and world politics: insights from sociology's institutionalism', International Organization 50, 2 (1996), pp. 325-47; Audie Klotz and Cecelia Lynch, Strategies for Research in Constructivist International Relations (M. E. Sharpe, Armonk, NY, 2007); and Karl E. Weick, Sensemaking in Organizations (Sage Publications, Thousand Oaks, CA, 1995). 
as how they will be interpreted (as worthy of international response or as domestic problems). Thus, frames and narratives do not cause action. Instead, they make action possible: they authorize, enable, and justify specific practices and policies (such as regulation of the mineral trade) while precluding others (such as resolution of land conflicts). These actions in turn reproduce and reinforce both the dominant practices and the meanings, embodied in frames and narratives, upon which they are predicated. Over time, the narratives and the practices they authorize come to be taken as natural, granted, and the only conceivable ones.

The literature on frames is also useful for understanding why certain narratives become dominant. It shows that certain stories resonate more, and thus are more effective at influencing action, when they assign the cause of the problems to 'the deliberate actions of identifiable individuals'; when they include 'bodily harm to vulnerable individuals, especially when there is a short and clear causal chain assigning responsibility'; when they suggest a simple solution; and when they can latch on to pre-existing narratives. ${ }^{10}$

As was evident from my fieldwork, the aspect of 'simplicity' - notably an uncomplicated story line, which builds on elements already familiar to the general public, and a straightforward solution - is particularly important in enabling a narrative to achieve and maintain prominence. Media outlets need to find a story that fits in a few pages, or can be told in a few minutes, and that their audience can easily understand and remember. Policy makers based in headquarters, such as desk officers and advisers to foreign and defence ministers, face a similar challenge for internal bureaucratic reasons. They are granted only a few minutes or a short memo to brief their superiors, who decide on the main policy directions, but usually have only a superficial knowledge of various conflict zones - and, for the most part, are not particularly interested in the Congo. They thus have to find a brief and straightforward presentation of the situation, with clear policy recommendations that their superiors can readily grasp and approve. Finally, aid organizations need to raise funds for their programmes, and advocacy agencies need to mobilize followers. As numerous staff members have explained to me, fundraising and advocacy efforts succeed best when they put forward a simple narrative, and the story is most likely to resonate with its target audience if it includes well-defined 'good' and 'evil' individuals, or clear-cut perpetrators and victims.

10. Kristin M. Bakke, 'Acceptance and resistance to foreign ideas: transnational insurgents' impact on the Chechen separatists' (Working paper, Department of Political Science, University College London, 2011), pp. 6-8; Margaret E. Keck and Kathryn Sikkink, Activists Beyond Borders: Advocacy networks in international politics (Cornell University Press, Ithaca, NY, 1998), p. 27; and David Lanz, 'Save Darfur: a movement and its discontents', African Affairs 108, 433 (2009), pp. 669-77. 
The need to find a simple narrative is all the more important in the case of the Congo given that policy makers, and the general public, usually perceive the conflict there as extremely complex and intractable. Virtually all my interviewees complained about the multiplicity of foreign and domestic actors involved in the violence, the seemingly endless character of the conflict, and the blurred lines between victims and perpetrators. Simple narratives are critical to helping deal with such complexity: they identify salient issues, dictate urgent action, and help determine who is worth supporting and who should be challenged.

Simple narratives are also essential given the poor quality of the information on the Congolese conflict. Apart from rare exceptions, international agencies involved in the Congo recruit their staff on the basis of their technical expertise - whether on humanitarian aid, development, peace building, or diplomacy, and not on their knowledge of the country. Before their deployment, newly hired staff members benefit, at best, from a few days of briefing on the country. Most interveners therefore lack contextual knowledge upon arrival in the field. When on the ground, they lack time to read the extensive literature on the conflict. They also lack reliable information on current events, as the material available is strikingly poor for a number of reasons - including an over-reliance on official data from UN and Congolese authorities, poor relationships between international interveners and their Congolese counterparts, lack of access to the most unstable areas, and the staff's inability to speak local languages. To make matters worse, meetings and reports usually provide factual information on security events, but rarely put these facts into a broader context, and almost never infer their meaning for the overall political, social, and economic situation. ${ }^{11}$ The rapid turnover of most international staff, who usually stay in the Congo for a period ranging between a few months and three years, compounds the lack of in-depth understanding of the conflict. Once again, simple, dominant narratives offer a way out of this predicament. They emphasize a few themes to focus on; interveners can then believe that they have a grasp of the most important features of the situation, instead of feeling lost and deprived of the knowledge necessary to properly accomplish their work.

Dominant narratives, however, are always contested, usually by marginalized voices. ${ }^{12}$ As a result, competing narratives abound. This article therefore traces the alternative narratives that various local and foreign

11. The weekly meetings organized by the UN Office for the Coordination of Humanitarian Affairs provide an excellent illustration of this claim. The main exceptions are the reports of the International Crisis Group and those of the UN Secretary General to the Security Council.

12. Kevin C. Dunn, Imagining the Congo: The international relations of identity (Palgrave Macmillan, New York, NY, 2003), and Klotz and Lynch, Strategies for Research. 
actors have developed to contest the dominant ones. I show that, even among international interveners, there is rising awareness that the dominant narratives on the Congo are too simplistic and that they obscure understanding.

Because of this unceasing contestation, dominant narratives are inherently unstable. Nevertheless, two mechanisms counteract the effects of contestation and lead most actors to reproduce the dominant narratives. To start with, people usually tend to 'interpret new information as a confirmation of [their existing] beliefs' ${ }^{13}$ In addition, large-scale bureaucracies, such as most international organizations and foreign ministries, are notoriously resistant to change because they rely on routines and stability to function and because change usually 'threatens entrenched organizational culture and interests'. ${ }^{14}$ Consequently, change in frames and narratives - and in the practices and policies they enable - usually takes place slowly and incrementally. ${ }^{15}$ The multiple actors who reproduce the narratives often do so with some degree of variation, which, over time, leads to a gradual evolution of the narratives. This is how sexual violence, once a neglected issue, has in the past ten years progressively become a central feature of the discourse on the Congo. One should note, however, that change can also take place rapidly, for example when marginalized voices suddenly become dominant (such as after decolonization) ${ }^{16}$ or when marginalized actors find a way to destabilize meanings, for instance by offering a new, more persuasive discourse at a time of crisis. ${ }^{17}$

Given that narratives orient action, it is important to study their impact on the ground. While most scholarly research has focused on the positive outcomes of various advocacy and norm-promotion efforts, several scholars have studied the negative consequences of dominant narratives. ${ }^{18} \mathrm{My}$ article builds on these analyses and goes one step further: in addition to explaining how narratives orient intervention at a macro-level, in

13. Weick, Sensemaking in Organizations, chapters 4 and 6.

14. Barnett and Finnemore, Rules for the World, p. 2; Eden, Whole World on Fire; and Catherine Weaver, Hypocrisy Trap: The World Bank and the poverty of reform (Princeton University Press, Princeton, NJ, 2008).

15. Weaver, Hypocrisy Trap, Chapter 2; Barnett and Finnemore, Rules for the World.

16. Dunn, Imagining the Congo.

17. Klotz and Lynch, Strategies for Research, p. 44.

18. With regards to the scholarly focus on positive outcomes, see Michael Barnett, 'Evolution without progress? Humanitarianism in a world of hurt', International Organization 63, 4 (2009), pp. 621-2; and David Lanz, 'The perils of saving strangers: Darfur and the politics of the responsibility to protect' (PhD proposal, University of Basel, 2010). On the negative consequences of dominant narratives, see David Kojan and Dante Angelo, 'Dominant narratives, social violence and the practice of Bolivian archaeology', fournal of Social Archaeology 5, 3 (2005), pp. 383-408; Mahmood Mamdani, Saviors and Survivors: Darfur, politics, and the war on terror (Pantheon Books, New York, NY, 2009), Part 1; and Roxanne Lynn Doty, Imperial Encounters: The politics of representation in North-South Relations (University of Minnesota Press, Minneapolis, MN, 1996). 
headquarters and national capitals, I also trace their effects at the microlevel, on the ground, where we can observe the actual consequences of the broader discourses. ${ }^{19}$

\section{The cause: conflict minerals}

The first dominant narrative holds that the illegal exploitation of mineral resources is the main source of violence in the Congo. ${ }^{20}$ Congolese minerals fund local and foreign armed groups who commit atrocities against the population. The solution is straightforward: to end war and violence, we should end the illegal trafficking of resources.

European advocacy NGOs such as Global Witness were the first to put forth this narrative in the late 1990s. Their campaigns led to the creation of a UN Panel of Inquiry that investigated the illegal exploitation of natural resources and other forms of wealth in the Congo. Along with the efforts of the European NGOs, the three reports that the Panel of Inquiry published between 2001 and 2003 put the topic of mineral resources firmly on the policy agenda. ${ }^{21}$ From then on, media reports multiplied, along with research on the link between mineral resources and violence in the Congo. ${ }^{22}$ Newly created US advocacy NGOs like Enough adopted the narrative and helped reinforce nascent interest on the subject in North America. By 2011, conflict minerals had become a requisite topic of conferences and writings on the Congo.

Think tanks, academics, Congolese intellectuals, and interveners on the ground regularly emphasize a number of competing narratives. They highlight the presence of foreign armed groups, Rwandan and Ugandan efforts to eradicate these militias, and the violent competition for power among Congolese leaders. Field-based international peace builders emphasize instead local drivers of tensions, such as land issues and grassroots antagonisms over traditional and administrative power. ${ }^{23}$ Academics and local populations also point to other economic sources of abuse

19. My approach is thus similar to that of R. Charli Carpenter, "Women and children first": gender, norms, and humanitarian evacuation in the Balkans 1991-5', International Organization 57, 4 (2003), pp. 661-94.

20. For a similar claim, see Laura Seay, 'Is Congo's mineral trade really the key to the country's conflict?', The Christian Science Monitor, 29 April 2011, <www.csmonitor.com/ World/Africa/Africa-Monitor/2011/0429/Is-Congo-s-mineral-trade-really-the-key-to-thecountry-s-conflict>.

21. UN Panel of Inquiry, 'Report of the panel of experts on the illegal exploitation of natural resources and other forms of wealth of the Democratic Republic of the Congo' (United Nations, New York, 2001 to 2003).

22. International Alert, 'The role of the exploitation of natural resources in fueling and prolonging crises in the eastern DRC' (International Alert, London, 2010), pp. 10-11, provides a very helpful review of this literature.

23. Autesserre, The Trouble with the Congo, chapters 2 and 4. 
beyond conflict minerals, notably disputes over cattle, charcoal, timber, drugs, and taxation at checkpoints. ${ }^{24}$ In fact, estimates show that only 8 percent of all conflicts are over natural resources. ${ }^{25}$

Although these competing narratives do influence the discourse on the Congo, the conflict minerals narrative has become so prominent that it often eclipses the others. The interviews I conducted with foreign interveners were clear in this regard. A number of them presented mineral resource trafficking as the main reason for Rwanda's involvement in the Congo and the only funding source for armed groups, although it is one among many and often not the largest contributor. ${ }^{26}$ Numerous interveners similarly emphasized that ending violence required first stopping the illegal exploitation of resources - although it is only one of several urgent steps necessary for ending tensions. The only other measure that these interviewees usually mentioned was the reconstruction of state authority, which they saw as necessary for better control over trade in minerals.

The actions of the countries and organizations most involved in the Congo also clearly illustrate how strongly this dominant narrative has influenced international action. Both panels of experts that the UN has created on the Congo have investigated the illegal exploitation of natural resources. ${ }^{27}$ While countries and organizations outside of the Great Lakes usually pay little attention to the Congo, Germany, the European Union, the OECD, the US, the UN, and the World Bank have all passed legislation or set up projects to reform the mining sector and help prevent the use of Congolese conflict minerals. ${ }^{28}$

The conflict minerals narrative has reached and maintained prominence in large part because it resonates with non-Congolese audiences. It latches onto a broader narrative on the economic dimensions of violence

24. Ann Laudati, "Unearthing the "resource curse": economies of violence beyond minerals in eastern DRC' (Working paper, Department of Environment and Society, Utah State University, 2011).

25. UN Integrated Bureau, 'Termes de référence: analyse des conflits' (Internal document, Kinshasa, 2011), p. 3.

26. Nicholas Garrett, 'Management of mineral resources in the DR Congo' (paper presented at the Workshop on The Post-Conflict State in the Democratic Republic of Congo, Johannesburg, 2009).

27. After the previously mentioned panel of inquiry handed in its last report in 2003, the UN created another group of experts to monitor the application of sanctions it had recommended. The group's reports clearly illustrate its continued focus on mineral resources. See, for instance, UN Security Council, 'Final report of the group of experts submitted through the Security Council committee established pursuant to Resolution 1533 (2004) concerning the Democratic Republic of the Congo' (United Nations, New York, 2010).

28. Didier Verbruggen, Evie Francq, and Jeroen Cuvelier, 'Guide to current mining reforms initiatives in eastern DRC' (IPIS, Antwerp, 2011), and Thierry Viercoulon, 'Derrière le problème des minerais des conflits, la gouvernance au Congo' (International Crisis Group, <www.crisisgroup.org/en/regions/africa/central-africa/dr-congo/derriere-leprobleme-des-minerais-des-conflits.aspx $>, 2011)$ provide very helpful overviews of these initiatives. 
and on the 'resource curse', which has dominated research on civil wars in the 2000s, and has led to high-profile policy initiatives such as the Kimberley Process. ${ }^{29}$ It assigns the cause of the problem to the deliberate actions of identifiable individuals (soldiers in various armed groups), references bodily harm to vulnerable people (the Congolese population), suggests a simple solution to the complex issue of the Congolese conflict (to end the illegal exploitation of resources) and enables the American and European publics to take action (by boycotting companies suspected of using conflict minerals). It also lets journalists and advocates tell the story of the Congo in a manner that the less-informed public can easily understand and relate to. As a journalist explained, 'the fact that I say coltan is in cell phones and your cell phone is supporting the conflict in Congo is a simplification of the conflict, but I would say it anyway, because we as journalists are trying to make things less foreign to a foreign audience'. ${ }^{30}$ The reactions of large parts of the Congolese elite and diaspora further legitimize this story line. Many of them contend that their country is victim of a global conspiracy in which Western powers support neighbouring states and foreign armed groups and fuel conflict on the ground in order to ease their access to Congolese natural resources. ${ }^{31}$ In this story, conflict minerals are, again, at the heart of the violence.

The illegal exploitation of resources is certainly an important cause of violence in the Congo. ${ }^{32}$ The advocacy efforts have thus achieved considerable results. They have helped bring international attention to the Congo. They have forced companies doing business there to consider whether their actions fuelled conflict. They have also made it more difficult for neighbouring countries to exploit Congolese minerals illegally. However, by focusing exclusively on one cause of violence, and one solution to it, the proponents of this narrative have inadvertently exacerbated the very problems they were combating. The dominance of this narrative has diverted attention from much-needed policy actions, such as the resolution of grassroots antagonisms, the fight against corruption, and the reform of the state administration.

29. Paul Collier and Anke Hoeffler, 'Greed and grievance in civil war' (Oxford Economic Paper 56, The World Bank, Washington, DC, 2001) launched this research programme. Subsequent studies include, among many others, the works of Paul Collier, Anke Hoeffler, David Keen, Michael Ross, Nicholas Sambanis, and numerous researchers affiliated with the World Bank.

30. Interview, Michael Kavanagh, Kinshasa, September 2010.

31. Autesserre, The Trouble with the Congo, pp. 17-18, discusses these conspiracy theories in depth.

32. Dan Fahey, Rethinking the Resource Curse: Natural resources and polywar in the Ituri district, Democratic Republic of the Congo (University of California-Berkeley, PhD dissertation, 2011); Michael Nest, Francois Grignon, and Emizet F. Kisangani, The Democratic Republic of Congo: Economic dimensions of war and peace (Lynne Rienner, Boulder, CO, 2006). 
Furthermore, in 2010 and 2011, as the international regulations came into effect and international pressure enticed Kabila to impose a temporary ban on mining operations in the Kivus and Maniema, it became clear that, given the conditions in the eastern Congo, such technical measures could not make any headway on their own. ${ }^{33}$ Even worse, as these measures were not accompanied by broader political, economic, military, and social reforms, they actually fuelled the problem they purported to combat. Since military leaders remained the principal power brokers in rural areas, and since corruption persisted, the application of the technical measures deprived vulnerable populations of their sole means of livelihood while allowing armed groups to continue and even expand their mining operations. ${ }^{34}$ Furthermore, many experts worried that the regulations would result in a de facto ban on Congolese mineral exports, given the near impossibility of implementing the required supply chain verification in the unstable conditions prevailing in the eastern Congo. ${ }^{35}$ This would lead either to a permanent loss of revenue for artisanal miners, their families, and the countless small businesses that depend on them, or to the replacement of ethically sound companies with rogue businesses that would ignore due diligence requirements. ${ }^{36}$

\section{The consequence: sexual violence}

Advocates of the conflict minerals narrative overwhelmingly focus on one specific consequence of the illegal exploitation of resources: rape and

33. A public source on this issue is Ruben de Koning, 'Conflict minerals in the Democratic Republic of the Congo - aligning trade and security interventions' (SIPRI Policy Paper 27, SIPRI, Stockholm, 2011).

34. Viercoulon, 'Derrière le problème des minerais'; UN Security Council, 'Report of the group of experts'; and Pole Institute, 'The North Kivu mining sector: report on the reopening of the mines' (Goma, April 2011).

35. For public sources, see Viercoulon, 'Derrière le problème des minerais'; Pole Institute, 'The North Kivu mining sector'; and Pole Institute, 'DRC: the mineral curse' (Regards Croisés, Goma, 2011).

36. The topics analysed in this paragraph have been at the heart of a heated debate, focused on the merits of the US regulation, and conducted in various blogs and newspapers. The most useful contributions include the blog Texas in Africa (by Laura Seay, <http:// texasinafrica.blogspot.com>, notably the post dated 13 December 2010); the blog Congo Siasa (by Jason Stearns, <www.congosiasa.blogspot.com>, notably the posts dated 3 and 10 August 2011); the blog of the Enough project (<www.enoughproject.org/blog>, notably the post dated 26 October 2011); the anonymous article "Africa and "Obama's embargo": a provision of Dodd-Frank boomerangs on the continent's poor', Wall Street Fournal, 18 July 2011, <online.wsj.com/article/SB10001424052748703956604576109773538681918.html>; David Aronson, 'How Congress devastated Congo', The New York Times, 7 August 2011, <www.nytimes.com/2011/08/08/opinion/how-congress-devastated-congo.html>; and Mvemba Dizolele, 'Conflict minerals in the Congo: let's be frank about Dodd-Frank', The Huffington Post, 22 August 2011, <sfbayview.com/2011/congo-let's-be-frank-about-DoddFrank/>. 
sexual torture of women and girls. ${ }^{37}$ More broadly, enormous attention is paid to the problem of sexual abuse in the eastern Congo, more than to any other form of violence. ${ }^{38}$ Margot Wallström, the UN Special Representative on Sexual Violence in Conflict, has dubbed the eastern Congo the 'rape capital of the world' and the 'most dangerous place on earth to be a woman', which are labels that journalists, advocates, and aid workers have used ad nauseam ever since. Rape is the main theme of countless media reports on the Congo. According to an insider, since 2009, there has been no interest in the Congo at the UN Security Council except when it discussed incidents of mass rapes and potential responses to them. Similarly, US State Department top officials reportedly pay no attention to the Congo except when sexual violence grabs the headlines. As a result, visiting a hospital treating victims of sexual abuse (notably the Panzi hospital in Bukavu or Heal Africa in Goma) seems to have become an obligatory stop during diplomatic visits to the eastern Congo, to the point that aid workers on the ground find it appalling. Sexual violence has also become a requisite topic of expertise for all people who work on the Congo. The Belgian foreign minister, for instance, feels obliged to react publicly to every case of mass rape in order to meet the expectation of his domestic audience. Finally, according to donors and aid workers, sexual violence is such a buzzword that many foreign and Congolese organizations insert references to it in all kinds of project proposals to increase their chances of obtaining funding.

Sexual violence has not always dominated the discourse on the Congo. During the large-scale fighting that took place between 1994 and 2003, even though sexual violence existed at higher levels than today, few people discussed it. They talked instead about violence in general and only a handful of humanitarian organizations had specific projects to help victims of sexual abuse. The 2002 report by Human Rights Watch on 'the war within the war' was the first to draw attention to this specific form of brutality. ${ }^{39}$ Journalists and news editors started favouring the sexual violence angle when talking about the Congolese conflict. The attention to this issue prompted NGOs to initiate projects on sexual abuse and to launch fundraising campaigns that reinforced interest in the topic. By all

37. A representative example of this focus, among many others, is the Enough Project Activist Brief, <http://enoughproject.org/files/certification_activist_brief.pdf> (June 2011). The post 'Is my cell phone full of rape, redux' on the blog Wronging Rights (by Kate Cronin-Furman, <wrongingrights.blogspot.com/2011/07/is-my-cell-phone-full-ofrape-redux.html>) provides links to many other examples.

38. Maria Eriksson Baaz and Maria Stern, 'The complexity of violence: a critical analysis of sexual violence in the Democratic Republic of Congo (DRC)' (SIDA and the Nordic Africa Institute, Stockholm, 2010), pp. 15-16 and 59, make a similar claim.

39. Human Rights Watch, 'The war within the war: sexual violence against women and girls in eastern Congo' (Human Right Watch, Washington, DC, 2002). 
accounts, the visit of Hillary Clinton to the eastern Congo in 2009, which focused on victims of sexual violence and resulted in an offer of millions of dollars in aid, and which was followed shortly after by a trip by Margot Wallström, entrenched sexual violence as the frame to use when thinking about the Congo. From then on, eastern Congo and rape became inextricably linked for most foreign audiences.

Congolese populations on the ground, Congolese intellectuals, and field-based interveners are the most vocal challengers of this narrative. They emphasize the many other consequences of violence, such as killings, forced labour, conscription of child soldiers, and non-sexual torture. There are several reasons, however, why the sexual violence narrative has reached and maintained prominence. To start with, the emotional impact of sexual violence is particularly strong, because of several characteristics. It involves intentionally inflicted bodily harm to individuals who are socially constructed as the most vulnerable (women and girls). It is viewed as the 'ultimate violation of self'. ${ }^{40}$ The consequences of this form of violence are also worse than others as, in addition to being tortured, victims are often subjected to social stigma and rejection by their communities. ${ }^{41}$ Most people thus react more strongly to cases of sexual violence than to other forms of abuse. Furthermore, in the Congo, the presence of sexual violence clashes with the image of the country as a pacified, post-conflict environment, which emerged during the transition to peace and became dominant after the 2006 post-war elections. ${ }^{42}$ At the same time, it fits perfectly with widespread stereotypes of Congolese people as savage and barbaric. $^{43}$ Moreover, the narrative resonates with audiences from all nationalities, as sexual abuse takes place everywhere. As a journalist explained, stories of rape are another way to make the Congolese conflict less foreign to the audience. The response of the public is unequivocal: this journalist noticed that, of all of his articles on the Congo, his stories on rape get the highest number of hits. ${ }^{44}$ Finally, the narrative includes a straightforward, feasible answer to the problem - to provide medical care

40. Justice Byron R. White, cited in many studies and articles on rapes, such as Suzanne Leone, 'Protecting rape victims' identities: balance between the right to privacy and the first amendment', New England Law Review 29, 1 (Spring) (1992-3).

41. Thanks to Meghan Foster-Lynch ( $\mathrm{PhD}$ candidate, Yale University) for suggesting this idea.

42. On the post-conflict label, see Autesserre, The Trouble with the Congo, pp. 65-8 and 100-2.

43. Maria Eriksson Baaz and Maria Stern, 'NAI researcher critical of rape report', <www. nai.uu.se/press/articles/nai-researcher-critical-o> (May 2011), and Howard French, 'Congo: rape, savagery, and stereotypes, the heart of darkness' (YouTube, <www.youtube.com/watch? $\mathrm{v}=\mathrm{NXJEVoaHoHU \& feature=}=$ player_embedded $>$ ). On the construction of the stereotyped view of Congolese people as barbaric, see Dunn, Imagining the Congo and Autesserre, The Trouble with the Congo, pp. 74-81.

44. Interview, Kavanagh. 
to victims of sexual abuse - and a possibility for people all over the world to get involved by sending money for projects helping rape survivors.

It is indisputable that everything should be done to stop the scourge of sexual violence in the Congo. Tens of thousands of Congolese are sexually assaulted every year; some of the rapes include horrific torture, and they almost always destroy the lives of the victims. The advocacy efforts have thus achieved a crucial outcome, by leading to the provision of much-needed help to the victims. However, this international focus has also led to unintentionally counterproductive results, namely discrimination against other vulnerable populations and, at times, an increase in the use of sexual abuse by combatants.

The overwhelming focus on sexual abuse against women and girls has led to discrimination against vulnerable populations in two ways. First, the concentration on sexual violence diverts attention from other forms of violence that are equally horrific, such as non-sexual torture, killings, and recruitment of child soldiers. ${ }^{45}$ For instance, the UN Development Programme's support to the reconstruction of the justice system focuses on enabling Congolese officials to respond to sexual abuses, instead of to all kinds of violent crime. ${ }^{46}$ The police mission of the European Union has only one unit deployed outside of the capital, and this unit focuses exclusively on the fight against sexual abuse, instead of on the fight against all illegal activities. During off-the-record interviews, Congolese and foreign aid workers regularly complained that they cannot draw the attention of the media or donors to horrific events that have no sexual dimension. They also complained that they receive more money than they need to treat victims of sexual abuse, while they lack funding to implement other crucial projects. The focus on sexual violence has actually shaped the provision of health services to such a point that Congolese women know that often the best, and sometimes the only way to obtain care is to claim to have been raped. ${ }^{47}$

A second problem is that, while there is enormous attention to violence against women and girls, there is little consideration of sexual abuse of men and boys. ${ }^{48}$ However, at least 4 to 10 percent of all rape victims are

45. French makes a similar point in 'Congo: rape, savagery, and stereotypes'.

46. UNDP North Kivu, 'Stabilisation et reconstruction de la RDC - Appui du PNUD' (Programme document, Goma, 15 December 2010).

47. A public source on this topic is Eriksson Baaz and Stern, 'The complexity of violence', pp. 61-3.

48. Public sources for this paragraph include Serena Cruz and Rosan Smits, 'Increasing security in DR Congo: gender-responsive strategies for combating sexual violence' (Clingendael Conflict Research Unit, The Hague, 2011); Chris Dolan, 'War is not yet over - community perceptions of sexual violence and its underpinnings in eastern DRC' (International Alert, Goma, 2010); Eastern Congo Initiative, 'Landscape analysis of community based organizations' (Seattle, 2011), p. 79; Eriksson Baaz and Stern, 'The complexity of violence', pp. 50-5; and Désirée Lwambo, "Before the war, I was a man": men and masculinities in eastern DR Congo’ (HEAL Africa, Goma, 2011). 
male, and their abuse also carries equally terrible psychological and physical consequences. Ignoring men and boys leads to discrimination in the provision of support to rape survivors. Framing sexual violence as a women's issue is also counterproductive, as it prevents constructive engagement with men - whether they are victims or perpetrators, power brokers or powerless - and thus cannot break the cycle of trauma and violence.

Even worse than discrimination against victims of different forms of abuse, the other main perverse consequence of this dominant narrative is that armed groups have started to perceive sexual violence as an effective bargaining tool. ${ }^{49}$ The singular focus on sexual violence signals that this form of abuse is particularly forbidden and punishable, and thus creates incentives for various groups to exploit it. While this mostly takes the form of threats of rapes in order to push for negotiations or end military operations, there are also examples of such threats being enacted, such as during the August 2010 mass rapes in Luvungi. A local militia called Mai Mai Sheka, which allied with the foreign rebel group the Democratic Forces for the Liberation of Rwanda, gang raped 387 civilians over the course of three days in a remote part of Walikale territory. According to several sources, Sheka ordered his soldiers to systematically rape women, instead of just looting and beating people as they usually do, because he wanted to draw attention to his armed group and to be invited to the negotiating table. ${ }^{50} \mathrm{He}$ knew that using sexual violence was the best way to reach this goal, because it would draw the attention of the international community, and various states and advocacy groups would put pressure on the Congolese government to negotiate with him - which is exactly what happened. Unfortunately, many other rebel leaders have used the same reasoning as Sheka and humanitarian organizations have observed an increase in the use of sexual violence by armed groups that have political claims.

This last unintended consequence would not exist if it were not for the presence of a final problem: there is much more attention, and many more projects, devoted to the consequences of sexual violence than to its causes, such as poverty, land conflict, hostile civil-military relationships, disorganization of the army and the police, weakness of the justice system, physical and economic insecurity, and oppressive gender norms. ${ }^{51}$ The

49. Maria Eriksson Baaz and Maria Stern, Sexual Violence in Conflict and Post-Conflict Settings: Perceptions, prescriptions, problems? (Zed Books, New York, NY, forthcoming 2012).

50. A public source is UN Security Council, 'Report of the group of experts', para. 41.

51. On the causes of sexual violence, see Cruz and Smits, 'Increasing security'; Dolan, 'War is not yet over'; Maria Eriksson Baaz and Maria Stern, 'Why do soldiers rape? Masculinity, violence and sexuality in the armed forces in the Congo', International Studies Quarterly 53, 2 (2009), pp. 495-518; Eriksson Baaz and Stern, 'The complexity of violence'; 
massive media coverage in the aftermath of the 2010 mass rapes in Luvungi is a case in point: all news items focused on the horrific nature of the violence, and on the UN failure to respond, while virtually none tried to explain why the soldiers decided to rape. The International Security and Stabilization Support Strategy provides a good illustration of how international contributions are used: 72 percent of the funds for sexual violence are devoted to treating victims of rape, and only 27 percent to preventing sexual abuse. ${ }^{52}$ The UN strategy on sexual violence presents a similar disproportion. ${ }^{53}$ Regrettably, the millions of dollars spent on this problem will never resolve it if they do not address its causes. Helping women who have been raped is imperative, but there is no doubt that the victims would have preferred an effective prevention programme, which would have spared them from assault in the first place.

\section{The solution: state building}

As was evident in my interviews, virtually all interveners saw the reconstruction of state authority in the east as the most effective way to end violence, including sexual abuse, and to stop the illegal exploitation of natural resources. ${ }^{54}$ Thus, one of the main priorities of the UN peacekeeping mission, as well as of numerous international donors and UN agencies, was to help the Congolese government extend its authority in the unstable eastern provinces. ${ }^{55}$

The focus on state building as the central solution to the complex problems of the Congo comes from two sources. First, diplomats and the leadership of international organizations are most comfortable with a state-to-state approach. ${ }^{56}$ They are trained to deal with state officials, and they see such interactions as the best way to respect the global norms of sovereignty and non-interference. It is therefore of utmost importance for these high-ranking interveners to ensure that they have counterparts with whom to interact. Second, from 2009 onward, international interveners believed that they had successfully implemented all the standard post-war solutions, notably general elections as well as national and regional

and Jocelyn Kelly, 'Rape in war: motives of militia in DRC' (USIP, Washington, DC, 2010).

52. Of these funds, 0.4 percent is devoted to data collection. See Système Intégré des Nations Unies, 'Stratégie internationale de soutien à la sécurité et à la stabilité de l'est de la RDC - Cadre programmatique intégré 2009-2010' (United Nations, Goma, 2010), p. 46.

53. Randi Sojhell, 'Soldiers without a cause? Explaining violence by the FARDC in the Congo' (paper presented at the annual meeting of the African Studies Association, Washington, DC, 2010).

54. See also Cruz and Smits, 'Increasing security', p. 1.

55. For a public source, see the mandate of the peacekeeping mission: UN Security Council, 'Resolution 1925 (2010)' (United Nations, 2010), section on stabilization.

56. Autesserre, The Trouble with the Congo, pp. 91-100. 
reconciliation. From their point of view, the remaining problems were thus due to criminality and other 'law and order' issues, which the Congo would be able to tackle if it were not a 'failed state'. ${ }^{57}$ Reconstructing state authority was a way to give the Congolese government the capacity necessary to address these domestic matters. At the same time, many international NGOs and church structures saw themselves as providing services that should be the responsibility of the state, such as health care and education. They therefore considered state building to be a sustainable exit strategy. ${ }^{58}$

The main problem with this strategy is that the Congolese state remains a predatory structure, as it has been during most of the Congo's history. ${ }^{59}$ Governmental officials are often preoccupied with using public offices as a means to accumulate personal wealth, even when it conflicts with the pursuit of the public good. ${ }^{60}$ State officials, including members of the army, the police, and the administration, continue to be responsible for the largest part of all human rights violations. ${ }^{61}$ Consequently, throughout the eastern Congo, people often experience the state as an oppressive, exploitative, and threatening machine, instead of seeing it as a structure set up for their benefit. Overall, large parts of the population survive in spite of the state rather than with its help.

While policy makers based in headquarters and national capitals often overlooked this problem, field-based interveners were painfully aware of it. There were thus nuances within the dominant narrative, notably different views of which components of the state structure interveners should emphasize. On-the-ground interveners and Congolese activists requested a strengthening of the justice system in order to end impunity and a reorganization of the armed forces in order to halt opportunistic violence. However, these advocacy efforts led to very few concrete results, as national and local authorities who benefited from the status quo met them

57. On the failed state label, see Kristof Titeca and Tom de Herdt, 'Real governance beyond the "failed state": negotiating education in the Democratic Republic of the Congo', African Affairs 110, 439 (2011), pp. 213-31. On the view of violence as criminality, see Autesserre, The Trouble with the Congo, pp. 72-4.

58. Thanks to Michelle Farley, from Wellspring Advisors, for suggesting this idea.

59. Trefon, Congo Masquerade. On the Congolese state before the war, see William Reno, Warlord Politics and African States (Lynne Rienner, Boulder, CO, 1998); and Crawford Young and Thomas Turner, The Rise and Decline of the Zairian State (University of Wisconsin Press, Madison, WI, 1985).

60. Transparency International, 'Corruption Perceptions Index' (Transparency International, Berlin, 2010).

61. Public sources include: International Crisis Group, 'Congo: pas de stabilité au Kivu malgré le rapprochement avec le Rwanda' (International Crisis Group, Brussels, 2010), pp. 9-11; UN Security Council, 'Report of the Group of Experts'; UN Human Rights Council, 'Third joint report of seven United Nations experts on the situation in the Democratic Republic of the Congo' (United Nations, 2011); and the weekly reports of the UN Office for the Coordination of Humanitarian Affairs. 
with resistance. Worse, the dominant narrative insisted so strongly on state building as the leading solution to violence that, despite their failure to promote accountability and respect for human rights, interveners preferred to implement any kind of state reconstruction project possible rather than no project at all. The international efforts thus focused on material reconstruction. Using funding from a number of bilateral and multilateral donors, $\mathrm{UN}$ agencies have built roads and administrative buildings, and have transported police and military forces to their new areas of deployment.

Unfortunately, extending the authority of a predatory state merely results in replacing one group of perpetrators (foreign and Congolese rebel groups) with another (state authorities and state security forces). Furthermore, it sometimes actually worsens living conditions for the population. For instance, Jeroen Adam and Koen Vlassenroot have masterfully demonstrated how the international efforts to reconstruct the taxation system became constitutive of the regime of predation. ${ }^{62}$ The aftermath of the 2010 mass rapes in Luvungi provides another telling illustration. In response to the attack, the Congolese army deployed a battalion to ensure the safety of the population and to dismantle the bases of the armed groups responsible for the assault. This operation caused the displacement of hundreds of people and was marred by numerous human rights violations, including 'rape, abduction and disappearance, perpetrated by [army] soldiers against civilians' ${ }^{63}$ In addition, outraged by the news of the mass rapes, high-level diplomats and UN officials vowed to bring justice to the victims. The UN thus helped deploy Congolese justice officials to conduct the investigation, but the proceedings were so poorly organized that they resulted in perpetrators threatening victims with death to discourage their testifying against them. ${ }^{64}$ To protect the victims, high-ranking interveners asked the peacekeeping mission to help station 100 Congolese police. Field-based peace builders tried to stall the process, as they knew that these underpaid police would be one more factor of insecurity in the area in the long run, but they eventually had to comply, which created another protection problem for an already sorely affected population.

62. Jeroen Adam and Koen Vlassenroot, 'The politics of taxation in eastern Congo' (paper presented at the annual meeting of the African Studies Association, Washington, DC, 2010).

63. MONUSCO and UN Human Rights Office of the High Commissioner, 'Final report of the fact-finding missions of the United Nations Joint Human Rights Office into the mass rapes and other human rights violations committed by a coalition of armed groups along the Kibua-Mpofi axis in Walikale territory, North Kivu, from 30 July to 2 August 2010' (United Nations, 2011), paras 39-41 and 58.

64. A public source on these events is UN Human Rights Office of the High Commissioner, 'Final report', p. 5 and para. 45. 
Interestingly, nobody I met challenged the emphasis on state building as the indispensable response to the ongoing conflict. There was no narrative emphasizing other modes of social organization beyond the state. ${ }^{65}$ When I asked interveners why they persevered even when there was no evidence that the presence of state authorities would benefit the population, and even when all available data suggested that state officials were likely to commit abuses, they answered that there was no alternative. Likewise, every Congolese I talked to, from poor peasants to high-level policy makers, presented the extension of state presence as an essential measure to end the violence. Even if they did not trust the police and the army, even if they had been victims of abuses in the past, they still hoped that state reconstruction would eventually better their living circumstances.

\section{Conclusion}

Policy analysts and academic researchers have paid enormous attention to the national and regional causes for the continuation of violence in the eastern Congo. This focus is legitimate, as domestic and foreign actors who incite fighting are mainly responsible for the ongoing human rights abuses. However, the analysis is incomplete if we overlook the unintended effects of well-intentioned international efforts.

Three related narratives dominate the discourse on the Congo and eclipse numerous competing framings of the situation. They emphasize one central cause (illegal exploitation of natural resources), one main consequence (sexual abuse of women and girls), and one key solution (reconstructing state authority). These dominant narratives have helped bring international attention to the Congo. They have challenged the view of the Congolese conflict as an intractable problem. They have made it possible for international interveners to identify concrete actions that would help improve the situation in the Congo. Indeed, these actions have assuaged some of the sources of violence, notably those linked to the exploitation of Congolese minerals. They have also enabled agencies to raise the funds necessary to provide much-needed help to victims of rape. However, by leading interveners to focus overwhelmingly on these issues, and to neglect other causes, consequences, and solutions, these narratives also have a number of perverse consequences. They obscure most interveners' understanding of the multi-layered problems of the Congo. They orient the intervention toward a series of technical responses and hinder

65. For examples of such narratives in other contexts, see James C. Scott, The Art of Not Being Governed: An anarchist history of upland Southeast Asia (Yale University Press, New Haven, CT, 2009). 
the search for a comprehensive solution. They lead interveners to privilege one category of victims over all the others. Even more disconcertingly, they reinforce the problems that their advocates want to address, notably by legitimizing state-building programmes that reinforce the harassment of the populations by state officials, and by turning sexual violence into an attractive tool for armed groups.

Developing policy recommendations to offset the negative impact of dominant narratives while preserving their positive outcomes would require an entirely new article. This one suggests several pointers, however. Advocacy organizations should emphasize the other causes and consequences of violence. In the short run, this would help raise funds to address these other issues, while, in the long term, it would reinforce the existing contestation of the dominant narratives and thus bolster the process of change. In addition, when reacting to cases of sexual abuse, top policy officials should consider using quiet diplomacy instead of public denunciations that produce results contrary to their intended goals. When funding sexual violence projects, donors should devote more money to addressing its causes. The reconstruction of state authority might help address sexual abuse and conflict minerals, but only if interveners fundamentally review their current strategy. They should halt the material programmes and, with those funds, consider paying the salary of state officials and security forces, as lack of income often leaves them no choice but to harass the population. Interveners should also refocus their efforts on strengthening the justice system and promoting respect for human rights, notably by using performance-based financing. Finally, they should help deploy additional security forces and state authorities only when they are properly trained, paid, and supervised. 